\title{
A Large Deletion of the Long Arm of Chromosome No. 4 in a Child with Limb Abnormalities
}

\author{
C. H. OCKEY, G. V. FELDMAN, M. E. MACAULAY, and M. J. DELANEY \\ From Paterson Laboratories, Christie Hospital and Holt Radium Institute, and \\ Duchess of York Hospital for Babies, Manchester
}

No case of complete monosomy for a human autosome has as yet been reported. Examples of the trisomic condition which is produced by the same mechanism of non-disjunction are, however, relatively frequent. It must be assumed, therefore, that the monosomic state is less viable than the trisomic. Partial monosomic conditions have been described, some of which are related to a definite syndrome spectrum, but even these are rare in the population. The most authenticated case of partial monosomy was that first described by Lejeune, Lafourcade, Berger, Vialatte, Boeswillwald, Seringe, and Turpin (1963) and termed 'cri-du-chat' because of the peculiar cat-like cry associated with the condition: 61 cases have now been observed (Lejeune, Lafourcade, Berger, and Rethore, 1966b). The chromosome constitution is characterized by a partial deletion of the short arm of one of the No. 5 pair, later confirmed by German, Lejeune, Macintyre, and de Grouchy (1964) using ${ }^{3} \mathrm{H}-$ thymidine autoradiography. Abnormalities associated with deletions of the short arm of chromosome No. 4 have also been reported by Hirschhorn, Cooper, and Firschein (1965), Wolf, Porsch, Baitsch, and Reinwein (1965a), Wolf, Reinwein, Porsch, Schröter, and Baitsch (1965b), and Leao, Neu, and Gardner (1966); none, however, show a common clinical syndrome (Table).

The most common partial monosomy, apart from the cri-du-chat, is that involving the deletion of the short arms of chromosome 18 (de Grouchy, Lamy, Thieffry, Arthuis, and Salmon, 1963). The cases so far reported have been summarized by Nitowsky, Sindhvananda, Konigsberg, and Weinberg (1966). Apart from the two cases of Cyclops reported by Faint and Lewis (1964) and Nitowsky et al.; no syndrome could be found. Partial deletion of the long arm of this chromosome seems less frequent and three cases have been described (de Grouchy, Royer, Salmon, and Lamy, 1964; Lejeune, Berger,

Received October 14, 1966.
Lafourcade, and Rethore, 1966a), with some indications that a clinical syndrome is present.

Other deletions reported involve the terminal segment of one arm of chromosome No. 3 (Patau, Opitz, and Dewey, 1964); part of the long arm of a group D chromosome (Lele, Penrose, and Stallard, 1963; Thompson and Lyons, 1965); a mosaic showing partial monosomy for the long arm segment of a $G$ group chromosome in one stem line with complete monosomy in the other was described by Lejeune, Berger, Rethore, Archambault, Jerome, Thieffry, Aicardi, Broyer, Lafourcade, Cruveiller, and Turpin (1964). Recently two further cases of this 'anti-mongolism' condition have been reported by Reisman, Kasahara, Chung, Darnell, and Hall (1966), and Engel, Hastings, Merrill, McFarland, and Nance (1966). We would like to report a new deletion involving the terminal segment of the long arm of chromosome No. 4 in a $3 \frac{1}{2}$-month-old boy, associated with the absence of most of the left forearm. The deleted chromosome was established as a No. 4 by arm ratio measurements and quantitative autoradiography.

\section{Case History}

This boy (S.B.) was born at term following a normal delivery. The pregnancy had been uneventful, and he was the first child of parents both of whom were 19 years old. His birthweight was $3600 \mathrm{~g}$. (7 lb. $15 \mathrm{oz}$.) and length $48 \mathrm{~cm}$. (19 in.). He was slow to breathe, but after mucus extraction and oxygen, by face mask, he breathed and cried satisfactorily.

At the first examination he was noted to have low-set ears, an upturned nose with depressed nasal bridge, a slight mongoloid slant of his eyes, only one bone in his left forearm, limitation of extension of the left elbow, and only one finger on this limb (Fig. 1-3). Both little toes were overriding, and there was a dislocation of the right hip.

He had a physiological jaundice which cleared rapidly, and he also developed pyrexia, the cause of which was not found; on the fifth day of life he had an episode of 


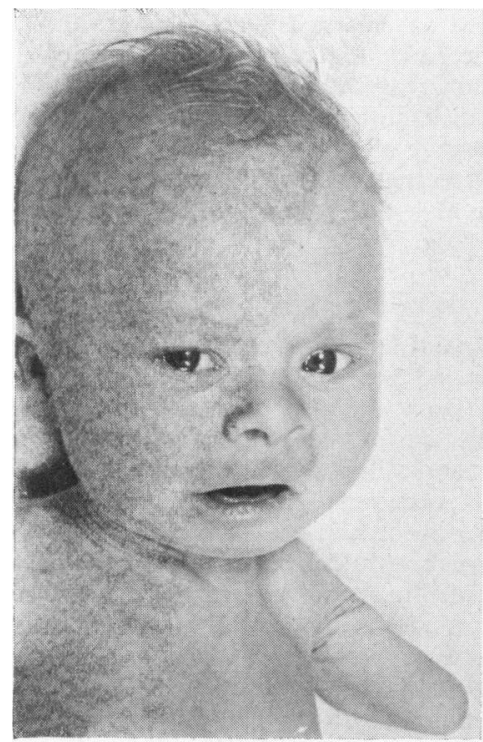

Fig. 1

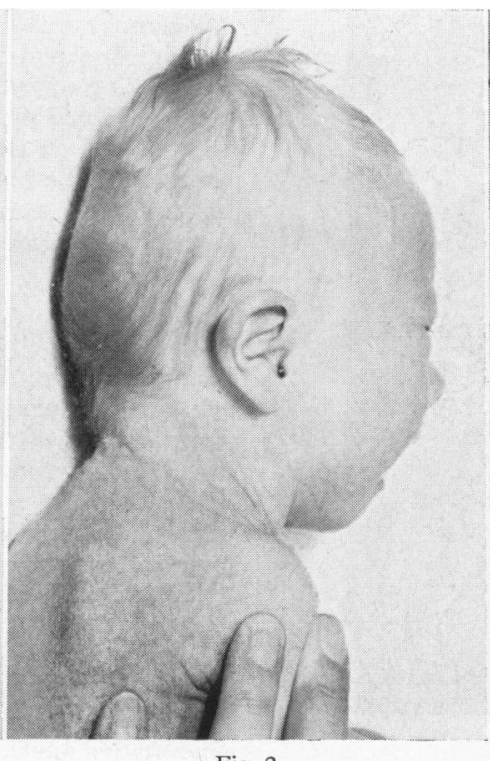

Fig. 2

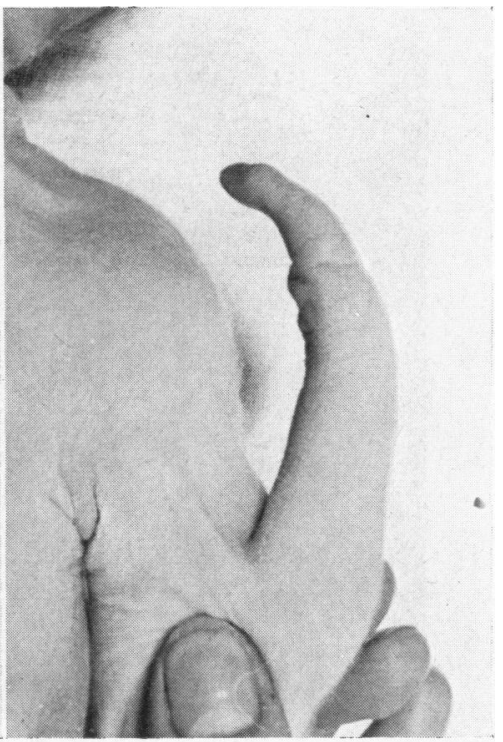

Fig. 3

Fig. 1-3.-Propositus.

generalized twitching. However, his condition improved, and he was allowed home.

At the age of 1 month he developed a respiratory infection and he became irritable and was noticed to become cyanosed during feeds; on this account he was readmitted to hospital for observation. At this time he was found to have a gastro-enteritis, and this became more severe after admission, persisting and resisting all therapeutic measures and, though there were brief remissions, his condition deteriorated and he died at the age of $3 \frac{1}{2}$ months, having developed a pneumonia terminally.

On admission, in addition to the abnormalities previously described, he was found to have a cardiac murmur

TABLE

Partial 4, 5 Monosomy

\begin{tabular}{|c|c|c|}
\hline Type of Deletion & Authors & Phenotype \\
\hline No. 5, short arm & $\begin{array}{l}\text { Lejeune et al. (1963); } \\
\text { Hijmans and Shearin (1965) }\end{array}$ & $\begin{array}{l}\text { Mental and growth retardation, microcephaly, hypertelorism, } \\
\text { epicanthic folds, anti-mongoloid slant to eyes, low-set } \\
\text { ears, cat-like cry, and moon-like facies }\end{array}$ \\
\hline No. 4, (?), short arm & Hirschhorn et al. (1965) & $\begin{array}{l}\text { 18-month-old boy. Mild myoclonic seizures, turret-shaped } \\
\text { head, midline scalp defect, coloboma, cleft palate, mild } \\
\text { neck webbing, second degree hypospadias, equinovarus, } \\
\text { large low-set ears }\end{array}$ \\
\hline No. 4, short arm & Wolf et al. (1965b) & $\begin{array}{l}\text { 31-year-old girl. Bilateral hare-lip, cleft palate, unfused } \\
\text { premaxilla, ectopia of pupil, low-set large ears, bilateral } \\
\text { pre-auricular sinus, sinus tachycardia, one cornea } \\
\text { enlarged, stenosis of left lachrymal duct, analgesia, } \\
\text { malformed cranium, hydrocephalus, skeletal abnormalities, } \\
\text { nystagmus, no eye blinking, seizures, mental } \\
\text { retardation, and failure to thrive }\end{array}$ \\
\hline No. 4, short arm & Leao et al. (1966) & $\begin{array}{l}\text { 4-month-old boy. Bilateral exophthalmos, broad nose } \\
\text { beaked tip, midline haemangioma of forehead, } \\
\text { asymmetrical face, left epicanthic fold, unequal labial } \\
\text { commissurae, praecordial systolic murmurs, inguinal } \\
\text { herniae, 1st degree hypospadias, and bilateral } \\
\text { undescended testes }\end{array}$ \\
\hline $\begin{array}{l}\text { No. 4, long arm } \\
\text { (terminal } 1 / 4)\end{array}$ & This report & $\begin{array}{l}\text { 31-month-old boy. Listless, enlarged heart, atrial and } \\
\text { ventricular septal defects, ductus arteriosus closed, } \\
\text { absence of left radius, carpal, and majority of metacarpals } \\
\text { and phalanges, dislocation of right hip and some } \\
\text { syndactyly of second and third toes }\end{array}$ \\
\hline
\end{tabular}




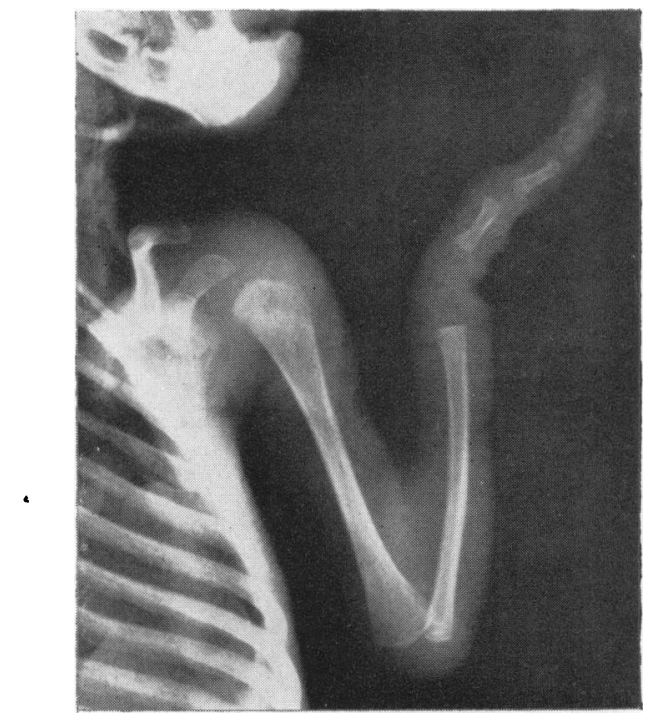

Fig. 4.-X-ray picture of left arm.

maximal in the second left interspace and at the apex; the pulmonary second sound was accentuated. There was clubbing of the fingers of the right hand.

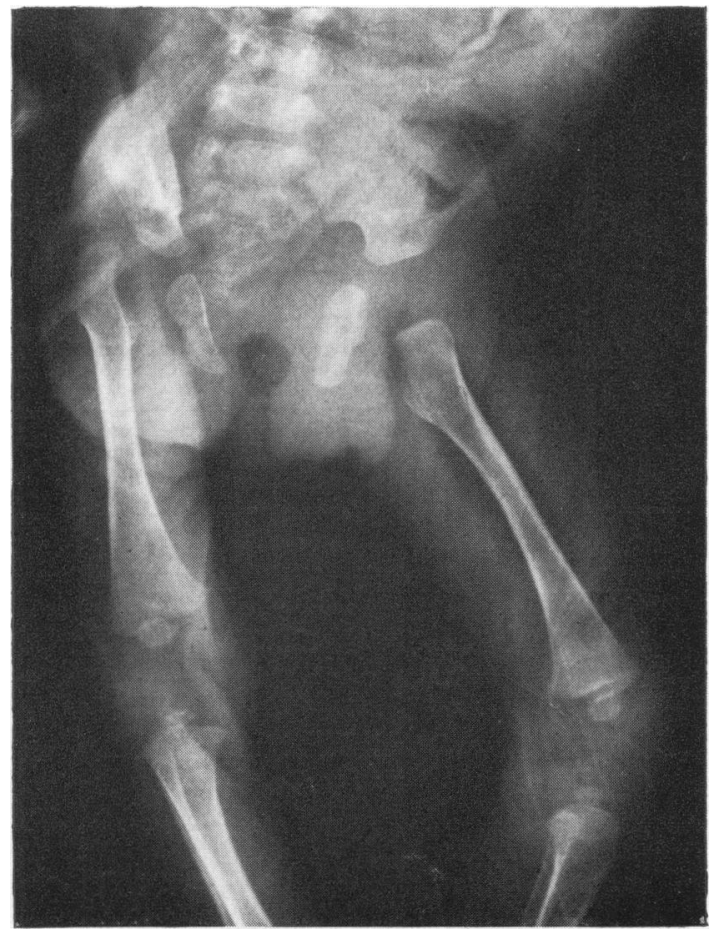

Fig. 5.-X-ray picture of hip.
Necropsy revealed an enlarged heart with atrial and ventricular septal defects. There was a consolidation of the left lung and some congestion of the right lung. One kidney showed mild dilatation of the calyces. The left arm showed an absence of the radius, carpals, and the majority of the metacarpals and phalanges (Fig. 4): the right arm was normal. There was also a dislocation of the right hip joint (Fig. 5).

\section{Investigations}

Three-day peripheral leucocyte cultures were set up from the propositus and from both parents; a skin biopsy was also cultured from the propositus. All cultures were labelled at the end of the DNA synthesis period with ${ }^{3} \mathrm{H}$-thymidine, and cells allowed to reach metaphases where they were accumulated with colcemid. A continuous labelling procedure was used for the leucocyte cultures (Gilbert, Muldal, Lajtha, and Rowley, 1962) and a pulse labelling technique for the fibroblasts (Ockey, Wennström, and de la Chapelle, 1966). The leucocyte cultures from both the propositus and the parents, though suitable for karyotype analysis and qualitative autoradiography, were of limited use for a quantitative analysis of grain distribution where a large number of good quality metaphases are required.

Thirty-three metaphase cells from the fibroblast cultures were used for both detailed karyotype and grain distribution analyses. The technique has been described previously (Ockey and de la Chapelle, 1967). The measurements for the mean lengths and arm ratios of the chromosomes were prepared from the 33 karyotypes (Fig. 6), while the linear grain densities of the segments of the relevant chromosomes were calculated by the method described by Gilbert et al. (1962), Ockey et al. (1966), and Ockey and de la Chapelle (1967). The histogram (Fig. 7) shows the linear grain densities of the various segments and indicates the late labelling regions as those with a linear grain density greater than 1 . Since the arbitrary chromosome segments used contain different proportions of late-labelling sites, the densities may vary from a high figure for 'complete' late-labelling segments, as with the late-labelling $X$, to a low figure for 'complete' early-labelling sements. The value of one is used as the dividing line in linear grain densities, since it is reached when all chromosome segments are labelling equally. The grain densities will also vary for a segment depending on the spectrum of cells analysed; extreme end of $S$ cells will show higher densities for certain late labelling sites compared to cells from a stage just prior to the end of S. There is also some indication, particularly with the sex chromosomes, that chromosomes from cells growing under different environmental conditions in vitro (Ockey, 1964) or from different tissues of the same individual (Utakoji and Hsu, 1965) may show differences in linear grain densities at the same stage of DNA synthesis.

\section{Results}

In all leucocytes and fibroblasts obtained from the propositus, 46 chromosomes were observed. The karyotype, however, was abnormal (Fig. 8). Only 
A Large Deletion of the Long Arm of Chromosome No. 4 in a Child with Limb Abnormalities 431

three chromosomes in the B group (Nos. 4 and 5) could be found, and there was an extra chromosome in group C. The chromosome constitution of both parents appeared normal.

Chromosome measurements. We have used arm ratio as the most reliable criterion to separate chromosomes Nos. 4 and 5 (Ockey and de la Chapelle, 1967). The chromosomes with the largest (long/short) arm ratio were also the more late-labelling pair, i.e. No. 4. However, if cells were chosen with either overcondensed chromosomes or with a pattern of labelling just before the end of the DNA synthesis period, then both pairs would become similar in arm ratio or in grain density, respectively. The arm ratio of the three $\mathbf{B}$ group chromosomes was calculated from the 33 cells analysed. Condensed or bent chromosomes were not included in the 33 cells analysed.

In each cell the chromosome with the largest arm
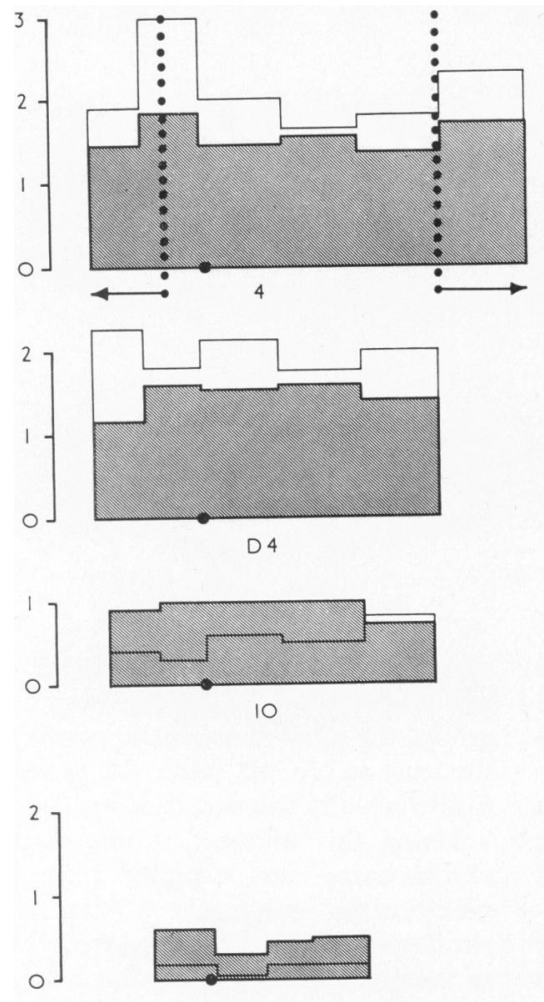

17

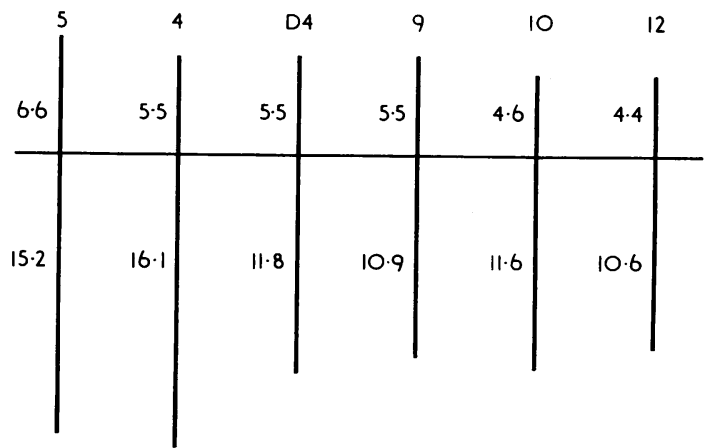

Fig. 6.-Ideogram of relevant chromosomes. Measurements in arbitrary units as means of lengths of each chromosome from the 33 cells analysed.

ratio was placed first and that with the smallest, last. The mean of each one gave $2 \cdot 91 \pm 0.04,2 \cdot 54 \pm$ 0.04 , and $2.49 \pm 0.04$, for the three chromosomes

Fig. 7.-Histogram of linear grain densities of relevant chromosomes. Hatched areas show the earlier $E_{1}$ stage of cells labelled at the end of DNA synthesis. The $E_{1}$ stage is calculated from the cells with the highest total grain counts. The clear areas show the later and adjacent stage of DNA synthesis $E_{2,3}$, and are based on cells with the lowest grain count. Vertical dotted lines show sites of published deletions. 


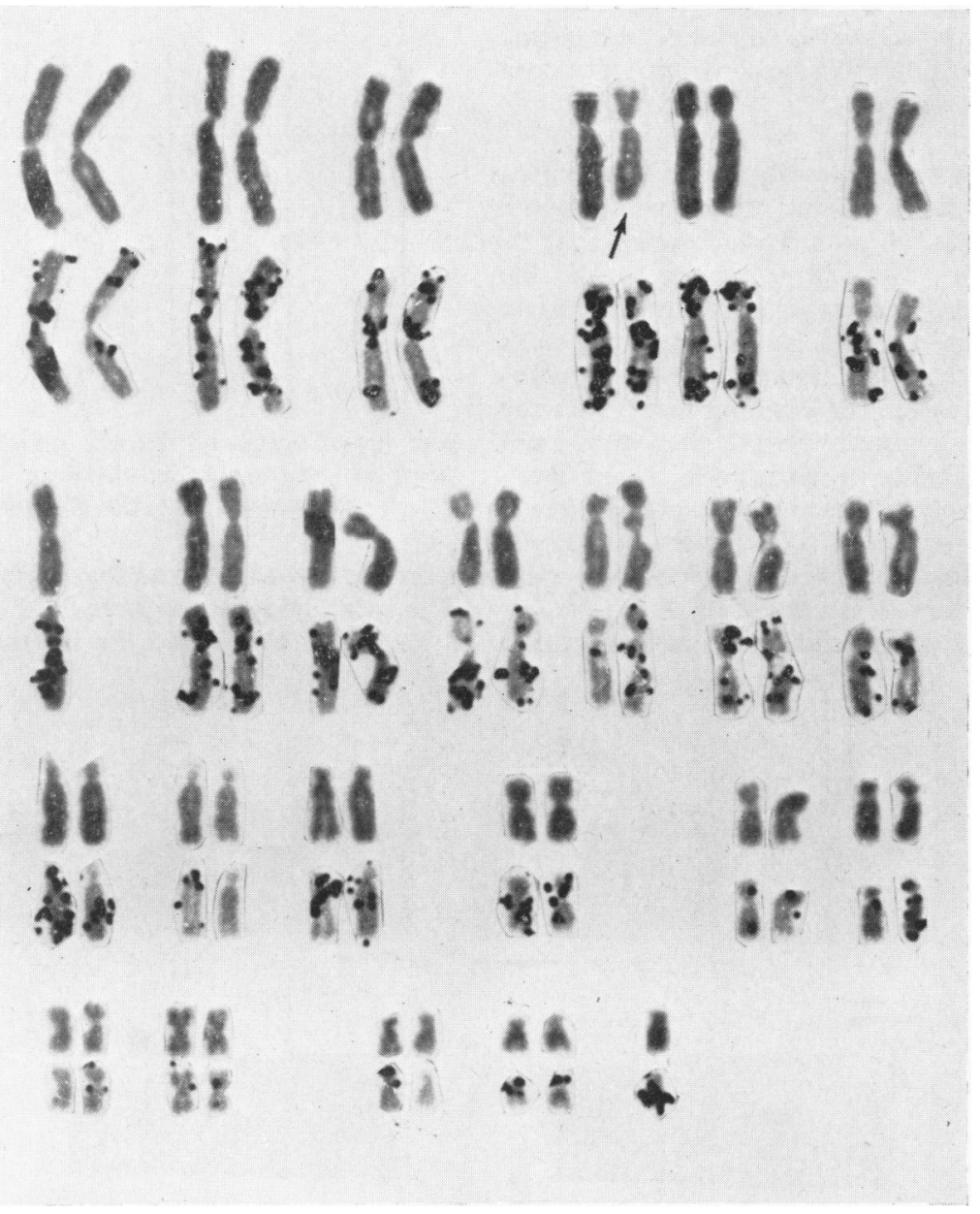

Fig. 8.-Karyotype and autoradiograph of fibroblast, with end of DNA synthesis pattern.

respectively. The arm ratio of the first selected chromosome was significantly different from the other two. This indicated that one normal No. 4 was absent.

The extra chromosome in group $\mathrm{C}$ could not be evaluated with any certainty. However, some attempt was made to select it, using a combination of arm ratio, length, and autoradiography. For karyotyping of group C chromosomes, our standard procedure is to divide the group into two on arm ratio. In the most metacentric group the No. 6 has the largest arm ratio. These chromosomes are then paired up on morphology and length. Of the most metacentric group, the smallest pair can be selected as No. 11, the largest as No. 6. The most metacentric chromosome or chromosomes of the remainder are selected as the $X$. The other two pairs, No. 7 and No. 8, are selected on length. In the second group, the most metacentric pair is selected as No. 9, the least as No. 10, while the remaining pair, which is also usually the shortest, as No. 12.

Using this method, it was found that an extra chromosome was usually placed into the least metacentric subgroup. This chromosome was similar to No. 9 and occasionally was distinguished as being slightly longer in its long arm. The mean measurements (Fig. 6), using this method of selection, showed that the long arm of this chromosome was approximately $23 \%$ shorter than that of the No. 4.

Autoradiography. In the majority of the 
autoradiographs of the 33 analysed cells (Fig. 8), the chromosome selected as the No. 4 was the most late labelling of the three in the B group. The two selected as No. 5 were often similar to each other in label distribution and showed the characteristic low label over the proximal segments of the long arm. When all the autoradiographs are expressed quantitatively the pattern becomes more obvious (Fig. 7). These results confirmed the presence of only one normal No. 4.

In group $\mathrm{C}$, the abnormal chromosome and the No. 9 pair selected on measurements were usually the three most late-labelling chromosomes in the least metacentric subgroup. Two of these chromosomes frequently showed a greater concentration of label in the proximal segment of the long arm, while the other was labelled more evenly in both its arms. This latter chromosome was selected as the abnormal one when this distinction was present. The label pattern and grain density of the abnormal $\mathrm{C}$ chromosome resembled that of the normal No. 4, if one assumed a deletion of the terminal part of the long arm. The high linear grain density of the proximal segment of its long arm indicated that some misclassification of these three chromosomes had occurred, since No. 9 usually shows a high density in this segment. We therefore concluded that our case represented a new deletion of about $23 \%$ of the long arm (terminal segment) of one of the No. 4 pair, and that probably the pattern of labelling of the deleted chromosome did not differ from the homologous region on the normal No. 4 .

Although both parents showed normal karyotypes and a qualitative autoradiographic analysis demonstrated in some cells two late-labelling chromosomes in group B, the possibility of a reciprocal translocation could not be ruled out. If such a translocation had occurred between the terminal segment of chromosome No. 4 and the telomere of No. 9, then the result would have been difficult to detect on either chromosome morphological or autoradiographical grounds. The deleted No. 4 would now appear as a No. 9, and the long No. 9 as a No. 4. No testicular biopsy from the father has yet been taken, where the presence of a quadrivalent at meiosis should indicate such a reciprocal translocation.

\section{Discussion}

Reciprocal translocations have been shown to involve the late-labelling or heterochromatic sites on the chromosomes more frequently than the earlier labelling regions (Ockey and de la Chapelle, 1967). It is, therefore, of interest to study the labelling behaviour of the published cases of deletions. These can be shown to involve a high frequency of late-labelling sites. Published cases involve deletions of the short arms of chromosomes Nos. 4, 5, and 18; the terminal segments of the long arms of a Group D (13-15), and a Group G (21-22) chromosome and Nos. 4 and 18. Some of these segments are shown in Fig. 7, demarcated by vertical dotted lines. All the segments, apart from those from the 21-22 chromosomes, and including the case described here, involve regions where the linear grain density is greater than 1 and are, therefore, late labelling.

The relation between genetical inactivity, heteropycnosis, and late-labelling behaviour in DNA synthesis of the $\mathrm{X}$ chromosome in mammals has been pointed out repeatedly by many authors. These segments are represented in interphase as chromocentres. Hsu (1962) demonstrated that they did not incorporate ${ }^{3} \mathrm{H}$-uridine and, therefore, presumably were inactive in synthesizing messenger RNA. They were also shown to be late labelling in DNA synthesis (Ockey, 1964).

It seems that these segments can be deleted from the chromosome complement and yet produce viable abnormal phenotypes. Deletions of similar size from genetically active regions are presumably less viable, since they are rarely observed. Minute deletions of these active regions presumably do occur, however, but are invisible using present cytological techniques, and would be regarded as cases with normal karyotypes. It appears likely, therefore, that the degree of abnormality is not related to the size of the deleted segment but to the amount and importance of genetically active regions contained in it.

\section{Summary}

A large chromosome deletion has been observed in a $3 \frac{1}{2}$-month-old boy. The child showed abnormalities of the left upper limb, a congenital heart defect, and dislocation of the hip. Quantitative morphological and autoradiographical analysis showed that a segment was deleted from the long arm of chromosome No. 4, amounting to $23 \%$. This deletion and most of those already reported involve segments containing a high proportion of late-labelling DNA and, therefore, presumably genetically inactive material. It is suggested that these represent only a small percentage of the actual deletions occurring.

The authors are grateful to Mr. D. T. Green for culturing and labelling some of the material; and to Drs. T. A. Harper, and J. Fawcett, and the resident staff of the Duchess of York Hospital for Babies, Burnage, Manchester, for generous co-operation in this study. 


\section{REFERENCES}

Engel, E., Hastings, C. P., Merrill, R. E., McFarland, B. S., and Nance, W. E. (1966). Apparent cri-du-chat and 'antimongolism' in one patient. Lancet, 1, 1130.

Faint, S., and Lewis, F. J. W. (1964). Presumptive deletion of the short arm of chromosome 18 in a cyclops. Hum. Chromos. Newsl., 14, 5.

German, J., Lejeune, J., Macintyre, M. N., and de Grouchy, J. (1964). Chromosomal autoradiography in the Cri-du-chat syndrome. Cytogenetics, 3, 347.

Gilbert, C. W., Muldal, S., Lajtha, L. G., and Rowley, J. (1962). Time-sequence of human chromosome duplication. Nature (Lond.), 195, 869.

de Grouchy, J., Lamy, M., Thieffry, S., Arthuis, M., and Salmon, C. (1963). Dysmorphie complexe avec oligophrénie: délétion des bras courts d'un chromosome 17-18. C.R. Acad. Sci. (Paris), 256, 1028.

—, Royer, P., Salmon, C., and Lamy, M. (1964). Délétion partielle des bras longs du chromosome 18. Path. et Biol., 12, 579.

Hijmans, J. C., and Shearin, D. B. (1965). Partial deletion of short arms of chromosome No. 5. Amer. F. Dis. Child., 109, 85.

Hirschhorn, K., Cooper, H. L., and Firschein, I. L. (1965). Deletion of short arms of chromosome 4-5 in a child with defects of midline fusion. Humangenetik., 1, 479.

Hsu, T. C. (1962). Differential rate RNA synthesis between euchromatin and heterochromatin. Exp. Cell Res., 27, 332.

Leao, J. C., Neu, R., and Gardner, L. I. (1966). Hypospadias and other anomalies associated with partial deletion of short arms of chromosome No. 4. Lancet, 1, 493.

Lejeune, J., Berger, R., Lafourcade, J., and Rethore, M. O. (1966a). Partial deletion of long arm of chromosome 18-a new autosomal syndrome. 3rd Intern. Cong. Human Genetics, p. 58 (Abstract).

- -, Rethore, M. O., Archambault, L., Jerome, H., Thieffry, S., Aicardi, J., Broyer, M., Lafourcade, J., Cruveiller, J., and Turpin, R. (1964). Monosomie partielle pour un petit acrocentrique. C.R. Acad. Sci. (Paris), 259, 4187.

, Lafourcade, J., Berger, R., and Rethore, M. O. (1966b).
Cri-du-chat syndrome, current stage of investigation. 3rd Intern. Cong. Human Genetics, p. 58 (Abstract).

,,-- , Vialatte, J., Boeswillwald, M., Seringe, P., and Turpin, R. (1963). Trois cas de délétion partielle du bras court d'un chromosome 5. C.R. Acad. Sci. (Paris), 257, 3098.

Lele, K. P., Penrose, L. S., and Stallard, H. B. (1963). Chromosome deletion in a case of retinoblastoma. Ann. hum. Genet., 27, 171.

Nitowsky, H. M., Sindhvananda, N., Konigsberg, U. R., and Weinberg, T. (1966). Partial 18 monosomy in the Cyclops malformation. Pediatrics, 37, 260.

Ockey, C. H. (1964). Recent evidence on the behaviour of sex chromatin (heterochromatin) from DNA labelling experiments. Symposia 'The Early Conceptus', p. 98. University of Dundee Press.

- , and de la Chapelle, A. (1967). Autoradiographic re-appraisal of an XXXXY male as a probable XXXXY with a 4/11 translocation. Cytogenetics, 6, 178.

—, Wennström, J., and de la Chapelle, A. (1966). Isochromosome-X in man. Part II. Hereditas (Lund), 54, 277.

Patau, K., Opitz, J. M., and Dewey, W. J. (1964). A multiple congenital anomaly in man presumably caused by a minute deletion in chromosome 3. Science, 146, 429.

Reisman, L. E., Kasahara, S., Chung, C.-Y., Darnell, A., and Hall, B. (1966). Anti-mongolism studies in an infant with a partial monosomy of the 21 chromosome. Lancet, 1, 394.

Thompson, H., and Lyons, R. B. (1965). Retinoblastoma and multiple congenital anomalies associated with complex mosaicism with deletion of $\mathrm{D}$ chromosome and probable $\mathrm{D} / 6$ translocation. Hum. Chromos. Newsl., 15, 21.

Utakoji, T., and Hsu, T. C. (1965). DNA replication patterns in somatic and germ-line cells of the male Chinese hamster. Cytogenetics, 4, 295.

Wolf, U., Porsch, R., Baitsch, H., and Reinwein, H. (1965a). Deletion on short arms of a B-chromosome without 'cri-du-chat' syndrome. Lancet, 1, 769.

- Reinwein, H., Porsch, R., Schröter, R., and Baitsch, H. (1965b). Defizienz an den kurzen Armen eines chromosoms Nr. 4. Humangenetik., 1, 397. 